\title{
家鬼耳殼湯傷に対する塩酸 Procaine 作用の 実験的研究
}

\author{
Seoul 大学校大学院（指道 張起呂教授） \\ 鄭奎澈
}

\section{I. 緒論}

1928年A. B. Bishnevsky') 忹急性炎症性疾患, 慢性潰 瘍, 脱疽, 火傷及び凍稘, 晹閉塞と陣痛障碍, 毛細管透 過性障㧹, 胸部橮稘, 呼吸因難等飞対し $0.25 \%$ 塩酸 Procaine 食塩水溶液の局所または交感神経䇥断術が良 好な効果を表す事を発表した. その治勃機転は前記諸種 疾患時, 悪変せる神経の伝導度が稀釈 Procaine 溶液に よって正常に回復されるためであると説明している。こ れを証明する実験として，氏は家鬼の横隔膜神経の伝導 度を Oscillograph で描写した結果，感染によって抑制 された同神経の伝導度は Procaine block によってそ の機能が回復されるのを観察した. その後 Traut 氏2) は塩酸 Procaine が Esterase によって速かに分解され る事を指摘し, 容易飞分解されない Procaine amide をRheumatoid arthritis 32例飞対し，経口的飞応用 したが有効例は 5 例澡きなかった. Gillespie と Henderson ${ }^{3)}$, Ruben と Mayer4) 及 び Millikan, Lundy, Smith ${ }^{5}$ 等諸氏は Cerebral thrombosis, embolism and spasm, Acute pulmonary embolism, Vague abdominal pain, Cansalgia 等に対して1\%塩酸 Procaine または $1 \%$ Efocaine で該当交感神経節を遮断し有効な結果を 得たと報告している. 一方, Betcher, Bean, Casten 諸 氏6)はすべての Chronic obliterative arteritis, Reflex sympathetic dystrophy, Visceral pain, Acute thrombophlebitis, Phlegmasia alba dolens 等飞対し, $1 \%$ 境酸 Procaine 10 ce 時間毎に持続的飞 Paravertebral block することによって交感神経節切除術に代る

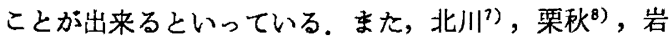
森諸氏!)は塩酸 Procaine を静脈内に注射すると疼痛を 除去するのみならず，不整脈，無尿症，術後気管枝拡張 症，血栓形成，破稘風，Allergy 性疾虫，Burger's disease，火甥及び凍俱にも有効であると発表した.

以上の文献を綜合するに，諸種矣患症候群と交感神経 系とは㙨能的に関連性のあることが知られる。交感神経
系の不調和及び機能障碍がその疾患の原因因子ではない そしろ，その変調せる機能を是正して，その疾患症候群 の柽減若しくは改善を招来して治虚に導くと思はれる. 火稘及び外匴に際し交感神経系に変化が招来されること は Larrey 氏以来よく知られているが，治療としての 塩酸 Procaine そついては未だ諭議が多い.

本研究は家鬼の耳殼湯傷に対する塩酸 Procaine の治 効作用を実験的に追究したものである.

\section{II. 実臨材料及び方法}

実験動物は体重 $2 \mathrm{~kg}$ 内外の成熟白色家鬼を用いた. 実験家鬼は耳款尖端から $5 \mathrm{~cm}$ までを $70^{\circ} \mathrm{C}$ 熱湯の佰温 水槽に 5 秒間浸して湯㑺を負はせた. 耳款湯賃負荷の温 度, 時間条件は予備実験によって決定した。（後述）

一群 4 匹からなる各湯傷負荷家鬼群に対しては塩酸 Procaine 食塩水溶液の局所注射, 頸部交感神経節遮断 及び静脈注射を逐時的飞行い, 湯第後の局所組織の变化, 特に湯甥部組織再生救出の程度を非処置群と各々比較観 察した. 塩酸 Procaine 食塩水溶液の投与法は次の如く である。

A. 局所浸潤注射法 : 湯匴部の下縁か 5 約 $5 \mathrm{~cm}$ 離れ て，Bishnevsky 氏法により0.25\%塩酸 Procaine 食塩 水溶液 $10 \mathrm{ce}$ 飞 $0.1 \%$ Adrenalin 1 滴を加へて注射し， 局所神経を遮断した。

B. 頸部交感神経節遮断法 : 家鬼の頭を実験側から反 対側に迴し，頸部を充分に伸ぼし，該当部を拇指で押え， 注射針を捅入して第 7 䫫椎の横突起飞到らしめ, 針先を 少し引出して横乫起の前面に沿って徐々に入れると椎体 の前面に当る.そこで注射器を吸引して血液, 気泡が出 ないのを確め，0.25\%㙉酸 Procaine 食壏水溶液 $10 \mathrm{cc}$ を注射した，神経節遮断の成功如何は注射側の Horner's syndrome, 耳殻の潮紅, 温感等で判断した.

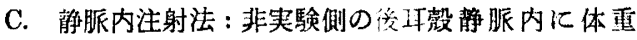
$1 \mathrm{~kg}$ 当り $4 \mathrm{mg}$ の塩酸 Procaine を生理的食塩水江溶 解し， $0.1 \%$ 溶液にして每分 $1 \mathrm{cc}$ つつ徐々に注入した。 
静脈注射群の対照群としては $0.1 \%$ 塩酸 Procaine 食塩水溶液の代りに同嘼の生理的食塩水を注射して比較 した.

北川 $7^{7}$, 栗林 ${ }^{8)}$, 林 ${ }^{19}$ )諸氏は体重 $1 \mathrm{~kg}$ 当り塩酸 Procaine $4 \mathrm{mg}$ を静脈注射するのが適切であるという が, これを再検討して, 無効量, 有効量, 中毒量及び致 死量を決定するため， 1 群 3 匹からなる各湯傷群に対し， 体重 $1 \mathrm{~kg}$ 当り各々 $2 \mathrm{mg}, 4 \mathrm{mg}, 6 \mathrm{mg}, 8 \mathrm{mg}$ づつを $0.1 \%$ 食塩水溶液にして湯賃直後静注し，その後24時間 毎に反椱した。更に各群 10 匹からなる 4 群に対しては $0.1 \% o ́ ， 0.25 \% ， 0.5 \%$ 及び $1.0 \%$ 塩酸 Procaine 食 塩水溶液を各々呼吸促迫, 唇部荅白, 全身座彎の起る迄 注射し，その注入量を測定した。

\section{III. 予 備 実 験}

湯傷部耳款組織の壊死脱落が Procaine 処置と非処置 によって差が現れる程度の湯傷を負はせるため, 各群 4 匹からなる家鬼の耳殼尖端を各々 $98^{\circ} \mathrm{C}, 80^{\circ} \mathrm{C}, 70^{\circ} \mathrm{C}, 65^{\circ} \mathrm{C}$ の熱湯に 5 秒間づつ浸して観察した。 その結果は次の如
くである.

$98^{\circ} \mathrm{C}$, , 5 秒湯傷群

湯倁即座飞局所組織の凝固を起し，28 30日後飞健部 から脱落した. (四表省略)

$98^{\circ} \mathrm{C}$ 群では 4 匹共湯甥即座に湯甥部の耳凯が完全に 凝固して白色を呈し，局所周囲资の徵候を見せ，28 30 日目脱落した。 $80^{\circ} \mathrm{C}$ 群 $70^{\circ} \mathrm{C}$ 群では湯甥後 7 日前後 飞局所組織が完全壊死を起し，2 3 週問目に脱落して いる。これに反し， $60^{\circ} \mathrm{C}$ 群は 5 日以内に湯傷部の組織 変化が正常江回復した。

以上の実験結果より, 本実験の湯傷負荷には $70^{\circ} \mathrm{C} の$ 熱湯飞 5 秒間作用させた。

\section{IV. 実 験 成 績}

1. 塩酸 Procaine 作用の効果と投与経路，耳殼湯倁 家忽群飞対し，何等の処置も施さない群 (対照群) と塩 酸 Procaine を各璉経路で投与した時の局所組織の壊死 脱落所見は次の如くである.

第 1 群は湯傷直後の変化として, 局所血管が抎張して

$80^{\circ} \mathrm{C} . ， 5$ 秒湯鹪群

\begin{tabular}{|c|c|c|c|c|c|c|c|c|}
\hline 所見 白数 & 第1日 & 第 2 日 & 第 3 日 & 第 4日 & 第 5 日 & 第 6 日 & 第 7 日 & 第17日7万至第 22 日 \\
\hline 変色状態 & 鮮 紅 & 鲜 紅 & 紫 紅 & 紫 紅 & 带黒褐 & 带黒褐 & 暗 褐 & \multirow[b]{2}{*}{ 眖落 } \\
\hline 硬 化 状 態 & 柔 & 柔 & 柔 & 一硬 & 硬 & 硬 & 硬 & \\
\hline 水泡形成 & $(-)$ & $(t)$ & $\begin{array}{l}\text { ero. } \\
(+)\end{array}$ & $\begin{array}{l}\text { ero. } \\
(+)\end{array}$ & 乾 壊 & 乾 壊 & 乾 境 & 级 \\
\hline 充 血 带 & $(-)$ & $(+)$ & $(+)$ & $(+)$ & $(+)$ & $(t)$ & $(+)$ & \\
\hline 循環 状態 & 拡 & 拡 & 拡 & $( \pm)$ & $(-)$ & $(-)$ & $(-)$ & \\
\hline 浮腫 状 態 & $(-)$ & $(+)$ & $(+)$ & $(+)$ & $( \pm)$ & $(-)$ & $(-)$ & \\
\hline 局 所 発 熱 & $(-)$ & $(+)$ & $(+)$ & $(+)$ & $(-)$ & $(-)$ & $(-)$ & \\
\hline
\end{tabular}

$70^{\circ} \mathrm{C} ., 5$ 秒湯甥群

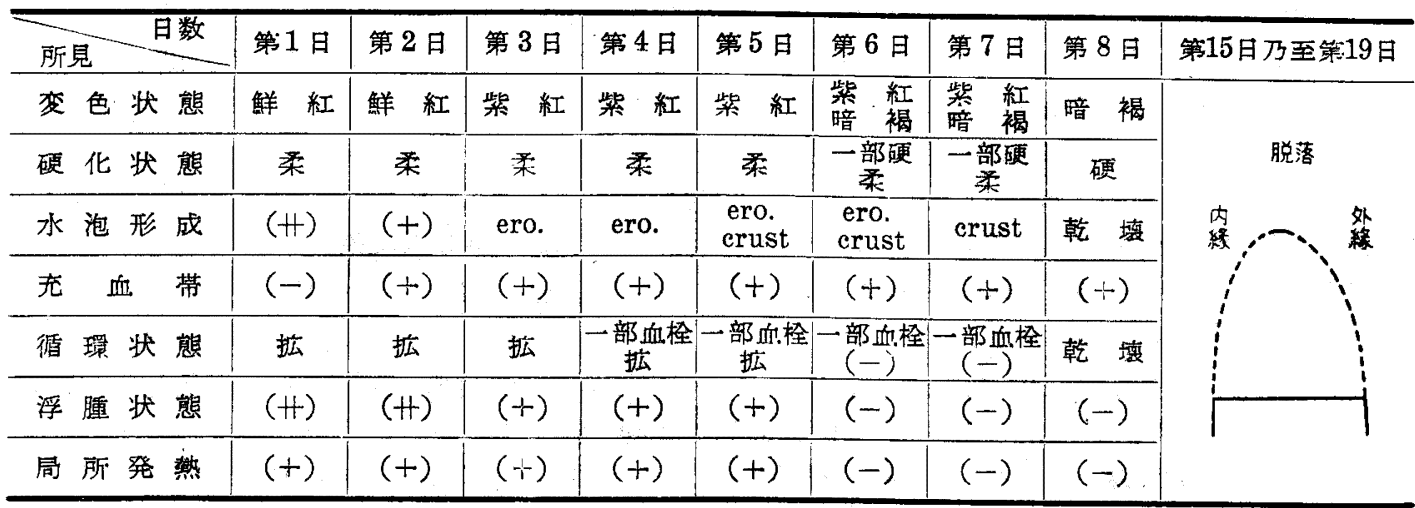


$65^{\circ} \mathrm{C}$., 5 秒湯僨群

\begin{tabular}{|c|c|c|c|c|c|c|}
\hline 所見 日数 & 第 1 日 & 第2 日 & 第 3 日 & 第 4 日 & 第 5 日 & 第 5 日以内 \\
\hline 变色状態 & 鮮紅 & 鮮紅 & 鲜紅 & 紅 & 紅 & \\
\hline 硬 化 状 態 & 柔 & 柔 & 柔 & 柔 & 柔 & \\
\hline 水泡形成 & $(+)$ & $(+)$ & 一部 & $(-)$ & $(-)$ & \\
\hline 充 血 帯 & $(+)$ & $(+)$ & $(+)$ & $(+)$ & $(+)$ & \\
\hline 循 環 状 態 & 拡 & 拡 & 拡 & $( \pm)$ & $(-)$ & \\
\hline 浮 腫 状 龍 & $(t)$ & $(t)$ & $(t)$ & $(-)$ & $(-)$ & \\
\hline 局 所 発 䓡 & $(+)$ & $(t)$ & $(+)$ & $(-)$ & $(-)$ & \\
\hline
\end{tabular}

第 1 群 : 非处置対照群（予備実呀の $70^{\circ} \mathrm{C}$. 群）

\begin{tabular}{|c|c|c|c|c|c|c|c|c|c|}
\hline 所見 日数 & 第 1 日 & 第 2 日 & 第 3 日 & 第 4日 & 第 5 日 & 第 6 日 & 第 7 日 & 第 8 日 & 第 15 日乃至第 19 日 \\
\hline 変 色 状 態 & 鮮“紅 & 鮮 紅 & 鲜 紅 & 紫 紅 & 紫 紅 & $\begin{array}{l}\text { 紫 紅 } \\
\text { 暗 褐 }\end{array}$ & $\begin{array}{ll}\text { 紫 } & \text { 紅 } \\
\text { 暗 褐 }\end{array}$ & 暗 褐 & \\
\hline 硬 化 状 態 & 莱 & 柔 & 柔 & 柔 & 柔 & $\begin{array}{c}\text { 一部硬 } \\
\text { 莱 }\end{array}$ & $\begin{array}{c}\text { 一部柔 } \\
\text { 硬 }\end{array}$ & 硬 & 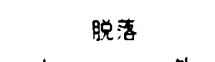 \\
\hline 水泡 形 成 & (H) & $(+)$ & ero. & ero. & $\begin{array}{l}\text { ero. } \\
\text { crust }\end{array}$ & $\begin{array}{l}\text { ero. } \\
\text { crust }\end{array}$ & crust & 乾 壊 & \\
\hline 充 血 帯 & $(-)$ & $(+)$ & $(+)$ & $(+)$ & $(+)$ & $(+)$ & $(+)$ & $(+)$ & \\
\hline 循 環 状 態 & 昖 & 拡 & 拡 & $\begin{array}{c}\text { 一部血烃 } \\
\text { 拡 }\end{array}$ & $\begin{array}{c}\text { 一部血栓 } \\
\text { 拡 }\end{array}$ & $\begin{array}{c}\text { 一部血栓 } \\
(-)\end{array}$ & 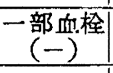 & 乾 填 & \\
\hline 浮 腫 状 態 & (H) & (H) & $(+)$ & $(+)$ & $(+)$ & $(-)$ & $(-)$ & $(-)$ & \\
\hline 同 所 発 楸 & $(+)$ & $(+)$ & $(+)$ & $(+)$ & $(+)$ & $(-)$ & $(-)$ & $(-)$ & \\
\hline
\end{tabular}

第 2 群 : 湯僨直後及びその後72時間毎に0.25\%塩酸 Procaine 食塩水溶液の局所注射を反覆した群

\begin{tabular}{|c|c|c|c|c|c|c|c|c|c|}
\hline 所見 $\quad$ 日数 & 第 1 日 & 第 2 日 & 第 3 日 & 第 4 日 & 第 5 日 & 第 6 日 & 第 7 日 & 第 8 日 & 第16日乃至第19日 \\
\hline 変色 状 㴔 & 紅 & 紅 & 紅 & 紫 紅 & 紫 紅 & $\begin{array}{l}\text { 一部褐 } \\
\text { 紫 紅 }\end{array}$ & 褐 & 暗 褐 & \\
\hline 硬 化 状 態 & 柔 & 柔 & 柔 & 柔 & 柔 & $\begin{array}{c}\text { 一部硬 } \\
\text { 柔 }\end{array}$ & 硬 & 硬 & \\
\hline 水泡形成 & $(+)$ & ero. & $\begin{array}{l}\text { ero. } \\
\text { crust }\end{array}$ & $\begin{array}{c}\text { ero. } \\
\text { crust }\end{array}$ & $\begin{array}{l}\text { ero. } \\
\text { crust }\end{array}$ & $\begin{array}{ll}\text { 部 } \\
\text { 乾 } \\
\end{array}$ & 乾 壊 & 乾 壊 & \\
\hline 充 血 率 & $(-)$ & $(+)$ & $(t)$ & $(+)$ & $(-t)$ & $(t)$ & $(+)$ & $(+)$ & \\
\hline 循環状態 & 拡 & 拡 & 拡 & $( \pm)$ & $( \pm)$ & $\begin{array}{ll}\text { 部 } \\
\text { 血 } \\
\end{array}$ & 血. 栓 & 血. 栓 & \\
\hline 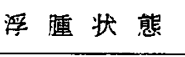 & (H) & (H) & $(+)$ & $(+)$ & $(+)$ & $( \pm)$ & $( \pm)$ & $(-)$ & \\
\hline 局 所 発 繁 & $(\div)$ & $(+)$ & $(-)$ & $(-)$ & $(-)$ & $(-)$ & $(-)$ & $(-)$ & \\
\hline
\end{tabular}

鮮紅色を呈し，搏動が触知されるが，約20分経っと湯伤 部表面は混濁腫悲を起し, 浮腫が甚しく, 搏動も触れず, 正常部との境界が明膫汇なった. 湯稘後 $2 \sim 3$ 時間以内 に水泡が生じ， 3〜4 日目から一部血管には血栓が形成 され，7〜8 日目には完全に乾性壊死を起した。壊死部 脱落までには15〜19日を要した。湯賃部組織が再生し救 山された所見は全然みられず，湯伤部と健部の境界は一
直線に分離した。

第 2 群は湯僨後 $4 \sim 6$ 日目から血栓を形成して乾性壊 死を起し始め， $6 \sim 8$ 日で局所組織は完全壊死した。壊 死部の脱落までには16〜19日を要した，全例において第 1 群飞較べ湯僛部組織が $100 \sim 140 \mathrm{~mm}^{2}$ 救はれている。 第 3 群は湯偒後 $5 \sim 6$ 日目から乾燥し始め, 完全壊死 までには $7 〜 81 ，$ 壊死部脱落までには16〜19日を要し 
第 3 群 : 湯賃直後及びその後72時間每に0.25\%塩酸 Procaine 食塩水溶液で頸部交感神経節遮断䚘を反覆 した群.

\begin{tabular}{|c|c|c|c|c|c|c|c|c|c|}
\hline 所見 日数 & 第 1 日 & 第 2 日 & 第 3 日 & 第 4 日 & 第 5 日 & 第 6 日 & 第 7 日 & 第 8 日 & 章16日乃至第19日 \\
\hline 変 色 状 態 & 鮮 紅 & 鲜 紅 & 鲜 紅 & 紫 紅 & 紫 紅 & 紫 紅 & $\begin{array}{c}\text { 一部紫紅 } \\
\text { 暗袒 }\end{array}$ & 暗 褐 & \\
\hline 硬 化 状 態 & 柔 & 柔 & 柔 & 柔 & 柔 & \begin{tabular}{c|} 
一部硬 \\
\end{tabular} & 若硬 & 硬 & \\
\hline 水泡形成 & $(+)$ & $(t)$ & ero. & $\begin{array}{l}\text { ero. } \\
\text { erust }\end{array}$ & $\begin{array}{l}\text { ero. } \\
\text { crust }\end{array}$ & $\begin{array}{c}\text { 乾 } \\
\text { crust }\end{array}$ & $\begin{array}{c}\text { 乾 } \\
\text { erust }\end{array}$ & 乾 壊 & \\
\hline 充 血. 带 & $(t)$ & $(t)$ & $(+)$ & $(t)$ & $(t)$ & $(+)$ & $(t)$ & $(+)$ & \\
\hline 循 環 状 驡 & 拡 & 拡 & 拡 & $(-)$ & $\begin{array}{l}\text {-部血栓 } \\
(-)\end{array}$ & 一部血栓| & 血 栓 & 血 栓 & \\
\hline 浮 腫 状 態 & (H) & (H) & $(+)$ & $(+)$ & $(+)$ & $(-)$ & $(-)$ & $(-)$ & \\
\hline 局 所 発 熱 & $(+)$ & $(t)$ & $(+)$ & $( \pm)$ & $(-)$ & $(-)$ & $(-)$ & $(-)$ & \\
\hline
\end{tabular}

第 4 群 : 湯賃直後及びその後72時間毎に家鬼の体重 $1 \mathrm{~kg}$ 当り $4 \mathrm{mg}$ の塩酸 Procine $0.1 \%$ 食塩水溶液 にして，静脈注射を反覆した群。

\begin{tabular}{|c|c|c|c|c|c|c|c|c|c|c|}
\hline 所見 旦数 & 第1日 & 第 2 日 & 第 3 日 & 第 4 日 & 第 5 日 & 第 6 日 & 第7 日 & 第 8 日 & 第 9 日 & 第16日7至第19日 \\
\hline 変色状驡 & 鲜 紅 & 鲜 紅 & 鲜 紅 & 鲜 紅 & 鲜 紅 & 柴 紅 & $\begin{array}{l}\text { 一部褐 } \\
\text { 柴 紅 }\end{array}$ & 紫部褐 & 褐 & 脱落 \\
\hline 硬化状態 & 柔 & 柔 & 柔 & 柔 & 柔 & 柔 & $\begin{array}{c}\text { 一部硬 } \\
\text { 柔 }\end{array}$ & 大部硬 & 硬 & \\
\hline 水泡形成 & $(+)$ & $\begin{array}{l}\text { ero. } \\
(+)\end{array}$ & $\begin{array}{l}\text { ero. } \\
(+)\end{array}$ & $\begin{array}{l}\text { ero. } \\
(t)\end{array}$ & $\begin{array}{l}\text { ero. } \\
\text { crust }\end{array}$ & $\begin{array}{l}\text { ero. } \\
\text { crust }\end{array}$ & 尖 乾 & 尖 乾 & 乾 壊 & \\
\hline 充 血 带 & $(+)$ & $(+)$ & $(+)$ & $(+)$ & $(+)$ & $(t)$ & $(t)$ & $(+r)$ & $(+)$ & \\
\hline 循環状態 & 拡 & 拡 & 拡 & 拡 & $( \pm)$ & $( \pm)$ & 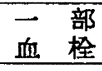 & 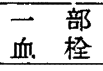 & 血 栓 & \\
\hline 浮腫状態 & $(+)$ & (H) & $(\#)$ & (H) & $(+)$ & $(+)$ & $(-)$ & $(-)$ & $(-)$ & \\
\hline 局所発熱 & $(+)$ & $(+)$ & $(+)$ & $(+)$ & $(-)$ & $(-)$ & $(-)$ & $(-)$ & $(-)$ & \\
\hline
\end{tabular}

第 5 群 : 湯傷直後及びその後 24 時間每に反覆静注せる群

\begin{tabular}{|c|c|c|c|c|c|c|c|c|c|}
\hline 所見 & 第1 日 & 第 2 日 & 第 3 日 & 第 4 日 & 第 5 日 & 第 6 日 & 第7 日 & 第 8 日 & 第:17日乃至第:18日 \\
\hline 変 色 状 態 & 鲜 紅 & 鮮 紅 & 紫 紅 & 紫 紅 & 紫 紅 & $\begin{array}{|ll|}\text { 尖 } & \text { 褐 } \\
\text { 紫 } & \text { 紅 } \\
\end{array}$ & $\begin{array}{l}\text { 喑 褐 } \\
\text { 紫 紅 }\end{array}$ & 暗 褐 & \\
\hline 硬 化 状 態 & 柔 & 柔 & 柔 & 柔 & 柔 & $\begin{array}{c}\text { 一部硬 } \\
\text { 柔 }\end{array}$ & $\begin{array}{c}\text { 硬 } \\
\text { 一部柔 }\end{array}$ & 硬 & \\
\hline 水泡形 成 & $(+)$ & $\begin{array}{l}\text { ero. } \\
(+)\end{array}$ & $\begin{array}{l}\text { ero. } \\
\text { crust }\end{array}$ & $\begin{array}{l}\text { ero. } \\
\text { crust }\end{array}$ & $\begin{array}{c}\text { 乾 } \\
\text { crust }\end{array}$ & $\begin{array}{ll}\text { 一 部 } \\
\text { 乾 塄 }\end{array}$ & $\begin{array}{l}\text { 大部分 } \\
\text { 乾 壊 }\end{array}$ & 乾 壊 & \\
\hline 充 血 带 & $(+)$ & $(+)$ & $(+)$ & $(+)$ & $(+)$ & $(+)$ & $(+)$ & $(+)$ & \\
\hline 循 環 状 態 & 拡 & 拡 & 拡 & （士） & $\begin{array}{c}\text { 一部血栓 } \\
( \pm)\end{array}$ & \begin{tabular}{|c|} 
一部血.栓 \\
$(-)$
\end{tabular} & $\begin{array}{l}\text { 大部分 } \\
\text { 血 栓 }\end{array}$ & 血 栓 & \\
\hline 浮 腫 状 態 & $(+)$ & (H) & $(+)$ & $(+)$ & $(-)$ & $(-)$ & $(-)$ & $(-)$ & \\
\hline 局 所 発 荆 & $(+)$ & $(+)$ & $(+r)$ & $(+)$ & $(-)$ & $(-)$ & $(-)$ & $(-)$ & \\
\hline
\end{tabular}

た. 湯賃部組織の救出は 95 160 $\mathrm{mm}^{2}$ で, 第 2 群飞類似 している.

第 4 群は湯僨後 4 日目から血栓を形成し始めたのが 2 例, 5 日目から始まったのが 1 例で, 残りの 1 例は 7 日 目から血栓を形成した．完全壊死までには 7〜9日を要
し，壊死部の分踓脱落には16〜19日を要した，全例に抢 ける湯㩐部組織の救出は第 2 群及び第 3 群より顕著で, $200 \sim 350 \mathrm{~mm}^{2}$ の範囲炕あった。

2. 塩酸 Procaine 投与の時間的関係

以上の成縝から最も効果のよかった静注群に対て, 湯 
第 6 群 : 湯甥 6 時間後及びその後 24 時間每に反覆萨注せる群

\begin{tabular}{|c|c|c|c|c|c|c|c|c|c|}
\hline 所見 日数 & 第 1 日 & 第 2 日 & 第 3 日 & 第 4 日 & 第 5 日 & 第 6 日 & 第 7 日 & 第 8 日 & 第17日乃至第;19日 \\
\hline 変 色 状 態 & 鲜 紅 & 紫 紅 & 柴 紅 & 紫 紅 & $\begin{array}{ll}\text { 青 } & \text { 白 } \\
\text { 柴 紅 }\end{array}$ & $\begin{array}{ll}\text { 青 } & \text { 白 } \\
\text { 䇣 } & \text { 紅 } \\
\end{array}$ & \begin{tabular}{ll|} 
黄 & 褐 \\
柴 & 紅
\end{tabular} & 褐 & \\
\hline 硬 化 状 態 & 柔 & 柔 & 柔 & 柔 & $\begin{array}{c}\text { 柔 } \\
\text { 一部峺 }\end{array}$ & $\begin{array}{c}\text { 柔 } \\
\text { 一部硬 } \\
\end{array}$ & 若 7 & 䂺 & \\
\hline 水泡形 成 & $(+)$ & ero. & ero. & $\begin{array}{l}\text { ero. } \\
\text { erust }\end{array}$ & $\begin{array}{l}\text { ero. } \\
\text { crust }\end{array}$ & 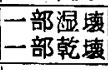 & $\begin{array}{l}\text { 一部湿㙍 } \\
\text { 一部乾壤 }\end{array}$ & 乾 填 & \\
\hline 充 血 带 & $(+)$ & $(+)$ & $(t)$ & $(+)$ & $(+)$ & $(t)$ & $(t)$ & $(t)$ & \\
\hline 循 環 状 驡 & 拡 & 拡 & （士） & $\begin{array}{l}\text { 部 } \\
\text { 血. 栓 }\end{array}$ & $\begin{array}{l}\text { 血，部 } \\
\text { 栓 }\end{array}$ & $\begin{array}{l}\text { 天部分 } \\
\text { 血. 栓 }\end{array}$ & $\begin{array}{l}\text { 大部分 } \\
\text { 血. 栓 } \\
\end{array}$ & 血. 栓 & \\
\hline 浮 腫 状 態 & $(t)$ & (H) & (H) & $(+)$ & $( \pm)$ & $(-)$ & $(-)$ & $(-)$ & \\
\hline 局 所 発 熱 & $(+)$ & $(+)$ & $(+)$ & $(-)$ & $(-)$ & $(-)$ & $(-)$ & $(-)$ & \\
\hline
\end{tabular}

第 7 群 : 湯甥 6 時間後及びその後72時間每に反覆静注せる群

\begin{tabular}{|c|c|c|c|c|c|c|c|c|c|}
\hline 所見 旦数 & 第 1 日 & 第2 日 & 第 3 日 & 第 4 日 & 第 5 日 & 第 6 日 & 第 7 日 & 第 8 日 & 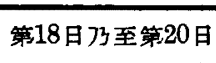 \\
\hline 変色 状態 & 鮮 紅 & 紫 紅 & 紫 紅 & $\begin{array}{l}\text { 尖青白 } \\
\text { 紫 紅 }\end{array}$ & $\begin{array}{l}\text { 尖青白 } \\
\text { 紫 紅 }\end{array}$ & $\begin{array}{l}\text { 尖黄褐 } \\
\text { 紫 紅 }\end{array}$ & $\begin{array}{ll}\text { 尖 } & \text { 褐 } \\
\text { 柴 } & \text { 紅 } \\
\end{array}$ & 暗 褐 & 脱落 \\
\hline 硬 化 状 態 & 柔 & 柔 & 柔 & 柔 & 柔 & 尖 硬 & 尖 硬 & 属 & \\
\hline 水泡 形 成 & $(+)$ & ero & $\begin{array}{l}\text { ero. } \\
\text { crust }\end{array}$ & 尖湿壊 & 尖湿壊 & 尖 乾 & 尖 乾 & 乾 壊 & \\
\hline 充 血 带 & $(+)$ & $+)$ & $(+)$ & $(+)$ & $(+)$ & $(+)$ & $(+)$ & $(+)$ & \\
\hline 循環 状態 & 拡 & 拡 & $(-)$ & $\begin{array}{c}\text { 一部血栓 } \\
(-)\end{array}$ & $\begin{array}{ll}\text { 二 部 } \\
\text { 血. 栓 }\end{array}$ & 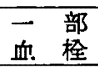 & $\begin{array}{l}\text { 大部分 } \\
\text { 血. 栓 }\end{array}$ & 血 & \\
\hline 浮腫状龍 & (H) & (H) & $(+)$ & $(-)$ & $(-)$ & $(-)$ & $(-)$ & $(-)$ & \\
\hline 局 所 発 熱 & $(t)$ & $(+)$ & $(+)$ & $(-)$ & $(-)$ & $(-)$ & $(-)$ & $(-)$ & \\
\hline
\end{tabular}

第 8 群 : 湯賃 12 時間後及びその後 24 時間每に反蕧静注せる群

\begin{tabular}{|c|c|c|c|c|c|c|c|c|}
\hline 所見 & 第 1 日 & 第 2 日 & 第 3 日 & 第 4 日 & 第 5 日 & 第 6 日 & 第 7 日 & 第:16日乃至第19日 \\
\hline 変色 状㑷 & 鲜 紅 & 紫 紅 & 紫 紅 & $\begin{array}{ll}\text { 尖 } & \text { 褐 } \\
\text { 紫 } & \text { 紅 } \\
\end{array}$ & $\begin{array}{c}\text { 大部分 } \\
\text { 褐 }\end{array}$ & 暗 褐 & 暗 褐 & 脱落 \\
\hline 硬 化 状 態 & 柔 & 柔 & 柔 & 尖柔 & $\begin{array}{l}\text { 大部分 } \\
\text { 硬 }\end{array}$ & $\begin{array}{l}\text { 若硬 } \\
\end{array}$ & 硬 & \\
\hline 水泡形成 & $(+)$ & $\begin{array}{l}\text { ero. } \\
\text { crust }\end{array}$ & $\begin{array}{l}\text { ero. } \\
\text { crust }\end{array}$ & $\begin{array}{c}\text { 尖辆壊 } \\
\text { crust }\end{array}$ & $\begin{array}{l}\text { 大部分 } \\
\text { 乾 壊 }\end{array}$ & $\begin{array}{l}\text { 大部分 } \\
\text { 乾 } \\
\end{array}$ & 乾 壊 & \\
\hline 充 血 带 & $(+)$ & $(t)$ & $(+)$ & $(+)$ & $(+)$ & $(+)$ & $(+)$ & \\
\hline 循 環 状 㮩 & 拡 & 拡 & 拡 & $\begin{array}{c}\text { 尖血栓 } \\
(-)\end{array}$ & $\begin{array}{l}\text { 大部分 } \\
\text { 血. 栓 }\end{array}$ & $\begin{array}{l}\text { 大.部分 } \\
\text { 血. 栓 }\end{array}$ & 血 栓 & \\
\hline 浮 蓮 状 龍 & $(+)$ & (H) & $(+)$ & $( \pm)$ & $(-)$ & $(-)$ & $(-)$ & \\
\hline 局 所発 燃 & $(+)$ & $(+)$ & $(+)$ & $(-)$ & $(-)$ & $(-)$ & $(-)$ & \\
\hline
\end{tabular}

伤後の塩酸 Procaine 投与の時間的関係を検討すへく， 1 群 3 匹よりなる湯賃群に対し第 4 群と同量, 同濃度の 塩酸 Procaine 食塩水溶液を湯偒後色々な時閒間隙をお いて静注して観察した結果は第 5〜8の各群に示す如く である。

第 5,6,7,8の各群は血栓形成まで $4 \sim 6$ 日, 湯伤部完 全壊死までは $7 \sim 9$ 日, 壊死部完全脱落までには16〜20
日を要した. 湯賃部組織の変化過程は各群共, 格別な差 異を認められなかったが，湯伤部壊死組織の救出面積は 第 5 群（湯伤直後及び24時間每に反䇣）では230 375 $\mathrm{mm}^{2}$,

第 6 群（湯甥 6 時間後及び 24 時間毎に反得）では 175 $\sim 280 \mathrm{~mm}^{2}$,

第 7 群（湯賃 6 時間後及び72時問每に反槽）ては 140 
第 9 群 : 生理的食㙋水を湯賃直後及びその後 24 時間毎に反覆静注せる群

\begin{tabular}{|c|c|c|c|c|c|c|c|c|c|c|}
\hline 所見 & 第 1 日 & 第 2 日 & 第 3 日 & 第 4 日 & 第 5 日 & 第 6.日 & 第 7 日 & 第 8 日 & 第 9 日 & 第16日乃引 \\
\hline 変色状態 & 鲜 紅 & 鮮 紅 & 鲜 紅 & 鮮 紅 & $\begin{array}{ll}\text { 尖 } & \text { 泉 } \\
\text { 紅 }\end{array}$ & $\begin{array}{ll}\text { 尖 } & \text { 泉 } \\
\text { 紧 }\end{array}$ & $\begin{array}{ll}\text { 尖 } & \text { 自紅 } \\
\end{array}$ & $\begin{array}{c}\text { 部青䄑 } \\
\end{array}$ & 暗 褐 & \\
\hline 硬化状㲘 & 柔 & 柔 & 柔 & 柔 & 柔 & 柔 & 柔 & 硬 & 硬 & \\
\hline 水泡形成 & $(t)$ & $(+)$ & ero. & $\begin{array}{l}\text { ero. } \\
\text { crust }\end{array}$ & $\begin{array}{l}\text { ero. } \\
\text { crust }\end{array}$ & 尖 & 湿尖 & 乾 壊 & 乾 壊 & \\
\hline 充血帯 & $(+)$ & $(+)$ & $(t)$ & $(t)$ & $(t)$ & $(+)$ & $(+)$ & $(+)$ & $(+)$ & \\
\hline 循環状態 & 拡 & 拆 & $\begin{array}{c}\text { 一部血栓 } \\
\text { 拡 }\end{array}$ & $\begin{array}{c}\text { 二部血栓 } \\
\text { 搪 }\end{array}$ & $\begin{array}{c}\text { 尖填死 } \\
(-)\end{array}$ & $\begin{array}{ll}\text { 部 } \\
\text { 血 }\end{array}$ & $\begin{array}{ll}\overrightarrow{\text { 部 }} \\
\text { 卹 }\end{array}$ & 血 栓 & 血 栓 & \\
\hline 浮腫状態 & $(+)$ & (H) & (H) & $(+)$ & $(+)$ & $(-)$ & $(-)$ & $(-)$ & $(-)$ & \\
\hline 局所発熟 & $(+)$ & $(t)$ & $(+)$ & $(-)$ & $(-)$ & $(-)$ & $(-)$ & $(-)$ & $(-)$ & \\
\hline
\end{tabular}

第10群 : 体重 $1 \mathrm{~kg}$ 当り塩酸 Procaine $2 \mathrm{mg}$ を静注せる群

\begin{tabular}{|c|c|c|c|c|c|c|c|c|c|c|}
\hline 見 & 第 1 日 & 第 2 日 & 第 3 日 & 第 4 日 & 第 5 日 & 第 6 日 & 第7日 & 第8日 & 第 9 日 & 阳 \\
\hline 変色状龍 & 鲜 紅 & 鮮 紅 & 鲜 紅 & 紫 紅 & 紫 紅 & $\begin{array}{l}\text { 尖谈裮 } \\
\text { 紫紅 }\end{array}$ & $\begin{array}{l}\text { 尖淡褐 } \\
\text { 紫青 }\end{array}$ & 褐 & 暗 褐 & \\
\hline 硬化状態 & 柔 & 柔 & 柔 & 柔 & 柔 & 尖柔 & 尖 ${ }^{\text {柔 }}$ & 硬 & 硬 & \\
\hline 水泡形成 & $(+)$ & $(+)$ & $(+)$ & $\begin{array}{c}\text { ero. } \\
(+)\end{array}$ & $\begin{array}{c}\text { erust } \\
(-)\end{array}$ & $\begin{array}{l}\text { 尖 乾 } \\
\text { 湿 }\end{array}$ & $\begin{array}{l}\text { 尖乾 } \\
\text { 湿 }\end{array}$ & 乾 塄 & 乾 壊 & \\
\hline 充血带 & $(-)$ & $(+)$ & $(t)$ & $(+)$ & $(+)$ & $(+)$ & $(+)$ & $(+)$ & $(+)$ & \\
\hline 循環状態 & 拡 & 拡 & 拡 & $\begin{array}{c}\text { 一部血柽 } \\
( \pm)\end{array}$ & 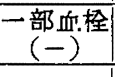 & $\begin{array}{ll}\overrightarrow{\text { 部 }} \\
\text { 血 }\end{array}$ & 血 栓 & 血 栓 & 血 栓 & \\
\hline 犬態 & H) & $(\pi)$ & $(+)$ & $(\div)$ & $(t)$ & $(+)$ & $(-)$ & $(-)$ & $(-)$ & \\
\hline 局所発倁 & $(+)$ & $(t)$ & $(+)$ & $(+)$ & $(+)$ & $(+)$ & $(-)$ & $(-)$ & $(-)$ & \\
\hline
\end{tabular}

第11群: 体量 $1 \mathrm{~kg}$ 当り塩酸 Procaine $4 \mathrm{mg}$ を静注せる群

\begin{tabular}{|c|c|c|c|c|c|c|c|c|c|}
\hline 所見 $\quad$ 日数 & 第 1 日 & 第2 日 & 第 3 日 & 第 4 日 & 第 5 日 & 第 6 日 & 第7 日 & 第 8 日 & 第17日乃至第18日 \\
\hline 変 色 状 顛 & 鮮 紅 & 鮮 紅 & 紫 紅 & 紫 䉺 & 紫 紅 & \begin{tabular}{|ll} 
尖 & 褐 \\
韭 & 紅 \\
\end{tabular} & $\begin{array}{ll}\text { 暗 } & \text { 褐 } \\
\text { 紫 } & \text { 紅 } \\
\end{array}$ & 暗 褐 & \\
\hline 硬 化 状 暜 & 柔 & 柔 & 柔 & 柔 & 柔 & $\begin{array}{c}\text { 一部硬 } \\
\text { 柔 }\end{array}$ & $\begin{array}{c}\text { 硬 } \\
\text { 一部柔 } \\
\end{array}$ & 硬 & \\
\hline 水泡 形 成 & $(+)$ & $\begin{array}{l}\text { ero. } \\
(+)\end{array}$ & $\begin{array}{l}\text { ero. } \\
\text { crust }\end{array}$ & $\begin{array}{c}\text { ero. } \\
\text { crust }\end{array}$ & $\begin{array}{c}\text { 乾 } \\
\text { crust }\end{array}$ & \begin{tabular}{|ll} 
乾 & 部 \\
\end{tabular} & $\begin{array}{l}\text { 大部分 } \\
\text { 乾 填 }\end{array}$ & 乾 壊 & \\
\hline 充 血 带 & $(+t)$ & $(+)$ & $(+)$ & $(+)$ & $(t)$ & $(+)$ & $(+)$ & $(+)$ & \\
\hline 循 環 状 龍 & 拡 & 拡 & 拡 & $( \pm)$ & 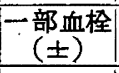 & $\mid \begin{array}{c}- \text { 部血检 } \\
(-)\end{array}$ & $\begin{array}{l}\text { 大部分 } \\
\text { 血 栓 }\end{array}$ & 血 栓 & \\
\hline 浮 腫 状 態 & $(+)$ & $(H)$ & $(+)$ & $(+)$ & $(-)$ & $(-)$ & $(-)$ & $(-)$ & \\
\hline 周 所 発 熱 & $(t)$ & $(+)$ & $(+)$ & $(t)$ & $(-)$ & $(-)$ & $(-)$ & $(-)$ & \\
\hline
\end{tabular}

$\sim 260 \mathrm{~mm}^{2}$,

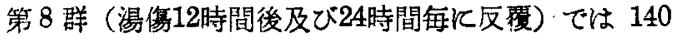
$\sim 175 \mathrm{~mm}^{2}$ であった.

壊死を起すべき湯傷部組織の再生救出状態は Procaine 静注を湯甥直後に行う方が良好で, 湯賃後初めての Procaine 静注が遅れる程効果が劣るようである.

塩酸 Procaine 食塩水溶液静注群の対照として, 同量
の食塩水溶液を第 5 群と同じ時間間隙をおいて静注した 時の所見は第 9 群の如くである.

第 9 群では湯賃後血栓形成までは $3 \sim 4$ 日，完全壊死 までは $6 〜 9$ 日, 壊死部脱落までは16〜20日を要した。 壊死すべき局所組織の再生救出状態は非処置対照湯篡群 と同しくく，全例に括いて少しす救はれずに脱落した。

3. 塩酸 Procaine の投与量 
第12群: 体量 $1 \mathrm{~kg}$ 当り塩酸 Procaine $6 \mathrm{mg}$ を静注せる群

\begin{tabular}{|c|c|c|c|c|c|c|c|c|c|c|}
\hline 新見 日数 & 第1日 & 第 2 日 & 第 3 日 & 第 4 日 & 第 5 日 & 第 6 日 & 第 7 日 & 第 8 日 & 第 9 日 & 第18日乃至第21日 \\
\hline 変色状態 & 鲜 紅 & 鮮 紅 & 鲜 紅 & 紫 紅 & 紫 紅 & 紫 紅 & 柴 青 & 柴 青 & 暗 褐 & \\
\hline 硬化状態 & 柔 & 柔 & 柔 & 柔 & 柔 & 采 & 柔 & 柔 & 硬 & \\
\hline 水泡形成 & $(+)$ & $(+)$ & $(+)$ & $( \pm)$ & $\begin{array}{l}\text { ero. } \\
\text { crust }\end{array}$ & $\begin{array}{l}\text { ero. } \\
\text { crust }\end{array}$ & 湿塤 & 湿埴 & 乾 液 & \\
\hline 充 血帶 & $(+)$ & $(+)$ & $(+)$ & $(t)$ & $(+)$ & $(t)$ & $(t)$ & $(+)$ & $(t)$ & \\
\hline 循環状態 & 拡 & 拡 & 抗 & 拡 & 拡 & $\begin{array}{ll}\overrightarrow{\text { 部 }} \\
\text { 血 }\end{array}$ & $\begin{array}{ll}\overrightarrow{0} & \text { 部 } \\
\text { 血 } & \text { 㻇 } \\
\end{array}$ & 血 栓 & 血 栓 & \\
\hline 浮隀状熊 & $(+)$ & $(t)$ & $(t)$ & $(+)$ & $( \pm)$ & $(-)$ & $(-)$ & $(-)$ & $(-)$ & \\
\hline 局所発熱 & $(+)$ & $(+)$ & $(+)$ & $(+)$ & $(t)$ & $(-)$ & $(-)$ & $(-)$ & $(-)$ & \\
\hline
\end{tabular}

第13群：体重 $1 \mathrm{~kg}$ 当り塩酸 Procaine $8 \mathrm{mg}$ を静注せる群

\begin{tabular}{|c|c|c|c|c|c|c|c|c|}
\hline 所見 日数 & 第 1 日 & 第 2 日 & 第 3 日 & 第 4 日 & 第 5 日 & 第 6 日 & 算7日 & 第17日乃至第20日 \\
\hline 変色状龔 & 鮮 紅 & 鲜 紅 & 紫 紅 & 紫 紅 & 紫 白 & 紫 白 & 暗 褐 & \\
\hline 硬 化 状 態 & 柔 & 柔 & 案 & 柔 & 柔 & 柔 & 硬 & \\
\hline 水泡形成 & (H) & (H) & (H) & $\begin{array}{l}\text { cro. } \\
\text { crust }\end{array}$ & 湿 壊 & 湿 填 & 乾 塭 & \\
\hline 充 血 率 & $(-)$ & $(+)$ & $(t)$ & $(t)$ & $(+)$ & $(+)$ & $(+)$ & \\
\hline 偱 環 状 㓤 & 拡 & 拡 & 拡 & 拡 & $\begin{array}{c}\text { 二部血栓 } \\
(-)\end{array}$ & 血 栓 & 血 栓 & \\
\hline 浮 腫 状 態 & (H) & (H) & $(+)$ & $(+)$ & $( \pm)$ & $(-)$ & $(-)$ & \\
\hline 局 所 発 熱 & $(+)$ & $(t)$ & $(+)$ & $(+)$ & $(-)$ & $(-)$ & $(-)$ & \\
\hline
\end{tabular}

第14群 : $1.0 \%$ 監酸 Procaine 食塩水溶液静脈注射量

\begin{tabular}{lcccc}
\hline 体重 & $\begin{array}{c}\text { 注射量 } \\
(\mathrm{cc})\end{array}$ & $\begin{array}{c}\text { Procaine 量 } \\
(\mathrm{mg})\end{array}$ & $\begin{array}{c}\text { 体重 1 Kg 当り } \\
\text { Procaine 量 } \\
(\mathrm{mg} / \mathrm{Kg})\end{array}$ & 備考 \\
\hline 2200 & $4.0-5.8$ & $40-58$ & $20.0-29.0$ & \\
2200 & $4.2-7.2$ & $42-72$ & $19.0-32.7$ & Dead \\
1800 & $3.7-6.3$ & $37-63$ & $20.6-35.6$ & \\
2000 & $3.6-5.6$ & $36-56$ & $18.0-28.0$ & \\
1800 & $3.5-7.0$ & $35-70$ & $19.5-38.9$ & Dead \\
2100 & $2.3-3.2$ & $23-32$ & $11.0-15.2$ & \\
1800 & $2.7-3.5$ & $27-35$ & $15.0-19.4$ & \\
1800 & $3.6-6.3$ & $36-63$ & $20.0-30.0$ & \\
2100 & $1.8-3.7$ & $18-37$ & $8.6-17.6$ & \\
1500 & $2.6-5.0$ & $26-50$ & $17.3-33.3$ & \\
\hline 15 & & & $16.9-27.9$ & \\
\hline
\end{tabular}

される如くである.

以上 4 群の成績中, 体重 $1 \mathrm{~kg}$ 当り塩酸 Procaine $2 \mathrm{mg}$ を投与せる第10群では他の 3 群より す血栓形成が $1 \sim 2$ 日促進された感があり, 湯伤 部組織の罣死程度も著しい。第 11 群 $(4 \mathrm{mg} / \mathrm{kg})$, 第12群 $(6 \mathrm{mg} / \mathrm{kg})$ ，第13群 $(8 \mathrm{mg} / \mathrm{kg})$ では一 般に似た成績である. 湯賃部壊死組織の救出も比 較的良好であったが，第 13 群（ $8 \mathrm{mg} / \mathrm{kg} ）$ はで 注射後身体の均衡を失い，しばらくの間よろめい た。

また，各群が10匹からなる 4 群に対して，0.1 $\%, 0.25 \%, 0.5 \%, 1.0 \%$ 塩酸 Procaine を 呼吸促迫，口唇部若白，全身症等の中毒症状が 現れるまで静注した結果は各々次の如くである.

第14群では $8.6 \sim 20.6 \mathrm{mg} / \mathrm{kg}$ (中畫量) の塩

1 群 3 匹からなる湯倁家鬼群に対し，体重 $1 \mathrm{~kg}$ 当り 酸 Procaine を各々 $2 \mathrm{mg}, 4 \mathrm{mg}, 6 \mathrm{mg}, 8 \mathrm{mg}$ づつ,

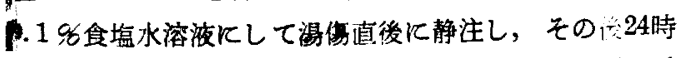

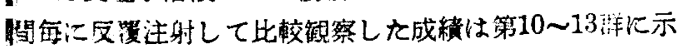

酸 Procaine る注入するや呼吸促進, 睹孔散大, 不安状 態等の中毒症状が現れ，15.2 38.9 $\mathrm{mg} / \mathrm{kg}$ （最少致死 晴）の注入では口镸部が菌白となり，呼吸はか心って抑

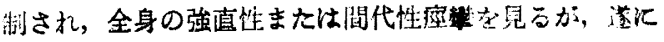


第15群 : 0.5\%監酸 Procaine 食塩水溶液静脈注射量

\begin{tabular}{lcccc}
\hline 体量 & $\begin{array}{c}\text { 注射量 } \\
(\mathrm{gm})\end{array}$ & $\begin{array}{c}\text { Procaine 量 } \\
(\mathrm{cc})\end{array}$ & $\begin{array}{c}\text { 体量 1 Kg 当り } \\
\text { Procaine } \\
(\mathrm{mg} / \mathrm{Kg})\end{array}$ & 備考 \\
\hline 1700 & $6.0-10.0$ & $30.0-50.0$ & $17.7-29.4$ & \\
2100 & $7.3-18.7$ & $36.0-93.5$ & $17.4-44.5$ & Dead \\
1700 & $6.5-11.2$ & $32.5-56.0$ & $19.1-32.9$ & \\
1900 & $6.4-12.0$ & $32.0-60.0$ & $16.8-31.6$ & \\
2500 & $7.6-16.8$ & $37.0-84.0$ & $14.8-33.6$ & \\
1900 & $6.1-14.2$ & $30.5-71.0$ & $16.1-37.4$ & \\
1800 & $6.3-12.9$ & $31.5-64.5$ & $17.5-35.8$ & \\
2000 & $8.3-14.6$ & $41.5-73.0$ & $20.8-36.5$ & \\
2200 & $8.8-15.1$ & $44.0-75.5$ & $20.0-34.3$ \\
1700 & $7.1-13.4$ & $35.5-75.5$ & $20.9-39.4$ \\
\hline 平均 & & & $18.1-35.4$ & \\
\hline
\end{tabular}

第16群 : 0.25\%塩酸 Procaine 食塩水溶液静脈注射量

\begin{tabular}{lcccc}
\hline 体重 & $\begin{array}{c}\text { 注射量 } \\
(\mathrm{gm})\end{array}$ & $\begin{array}{c}\text { Procaine 量 } \\
(\mathrm{cc})\end{array}$ & $\begin{array}{c}\text { 体重 1 Kg 当り } \\
\text { Procaine } \\
(\mathrm{mg} / \mathrm{Kg})\end{array}$ & 備考 \\
\hline 2000 & $15-23$ & $37.5-57.5$ & $18.8-28.8$ & \\
1800 & $23-37$ & $57.5-92.5$ & $31.9-51.4$ & Dead \\
2000 & $16-31$ & $40.0-77.5$ & $20.0-38.8$ & \\
1700 & $10-24$ & $25.5-60.0$ & $14.9-35.3$ & \\
2000 & $13-23$ & $32.5-57.5$ & $16.3-28.8$ & \\
1600 & $9-24$ & $22.5-60.0$ & $14.1-37.5$ & \\
2100 & $16-29$ & $40.0-72.5$ & $19.1-34.5$ & \\
1900 & $13-25$ & $32.5-62.5$ & $17.1-32.9$ & \\
2000 & $15-27$ & $37.5-67.5$ & $18.8-33.8$ \\
1700 & $11-23$ & $27.5-57.5$ & $16.2-28.8$ \\
\hline 平均 & & & $17.9-35.4$ & \\
\hline
\end{tabular}

第17群 : 0.1\%塩酸. Procaine 食塩水溶液静腿注射量

\begin{tabular}{lccc}
\hline 体重 & $\begin{array}{c}\text { 注射量 } \\
(\mathrm{gm})\end{array}$ & $\begin{array}{c}\text { Procaine 量 } \\
(\mathrm{cc})\end{array}$ & $\begin{array}{c}\text { 体量 1 Kg 当り } \\
\text { Procaine } \\
(\mathrm{mg} / \mathrm{Kg})\end{array}$ \\
\hline 1700 & $34-60$ & $34-60$ & $20.0-35.3$ \\
1700 & $34-64$ & $34-64$ & $20.0-37.1$ \\
2000 & $33-74$ & $33-74$ & $16.5-37.0$ \\
1400 & $23-53$ & $23-53$ & $16.4-37.9$ \\
1700 & $26-49$ & $26-49$ & $15.3-28.8$ \\
1800 & $43-61$ & $43-61$ & $23.9-33.9$ \\
2000 & $39-63$ & $39-63$ & $19.5-31.5$ \\
2100 & $38-68$ & $38-68$ & $18.1-32.4$ \\
1900 & $48-67$ & $48-67$ & $25.3-35.3$ \\
1600 & $36-53$ & $36-53$ & $22.5-33.1$ \\
\hline 平均 & & & $19.8-34.2$ \\
\hline
\end{tabular}

は完全弛緩して $4 \sim 5$ 分後に回復し，身体の均衡 も維持できた．10例の中 2 例は完全弛䋧状態から 回復せず，呼吸麻㾘によって死亡した。

第15群の中毒量は $14.8 \sim 20.9 \mathrm{mg} / \mathrm{kg}$ ，最少致 死量は $29.4 \sim 44.5 \mathrm{mg} / \mathrm{kg}$ で，10例中 1 例が死 亡した.

第16群の中毒量は $14.1 \sim 13.9 \mathrm{mg} / \mathrm{kg}$ ，最少致 死量は $28.8 \sim 51.4 \mathrm{mg} / \mathrm{kg}$ であった. 10例の中 1 例が死亡した。

第17群の中毒量は $15.3 \sim 25.3 \mathrm{mg} / \mathrm{kg}$ ，最少致 死量は $28.8 \sim 37.9 \mathrm{mg} / \mathrm{kg}$ で死亡例はなかった.

\section{v. 考案}

塩酸 Procaine の治効作用に関しては多くの学 者によって報告されているが，その作用機転に対 しては未だ意見が異る.

A. B. Bishnevsky 1) は塩酸 Procaine の治効作 用は神経反射によって，急性感染症の病因である 栄養神経の変調が回復されるためであり，火傷後 5 時間以内に0.25\%塩酸 Procaine block を行へ ば，火傷の各度を一つづ非減するととが出来る と言った.

DeTakats 氏 ${ }^{10}$ ) 卒倒時の応急炕置として行う 星状神経節遮断の理由として，(1)臨床的飞神経症 状及び症候が改善される点，(2)脳血管抵抗の低下 する点, (3)脳栓塞で死亡した患者の剖検結果, そ の約40\%のみが Embolism, Thrombosis または Arteriosclerosis 等によって脳血管が閉塞された 事実より，脸貧血の原因は血管収縮であるという 点，(4)星状神経節を遮断することによって脳の血 管分布が増加される点，(5)動物で頸部交感神経節 を刺戟すると反側の頭蓋腔内血管が拡張される点 等を挙付，その効果を強調している，星状神経節 遮断で効果の得られないのは頭蓋腔内出血及び浮 腫, 継続的な脳室内の出血のためであり，また选 断を余り遅く行うとか，甚しき血管硬化症がある とか, Shock 状態飞あるとか, 意識輩失或は Circle of Willis 飞機能不全があるためであるという.

一方, Walter C. Alvarez ${ }^{11)}$ は星状神経節を遮 断しても脳の動脈を大きく拡張することが出来ず, 或は，しばしば血管が拡張されたにしても，血栓 が他の所に生じて血流が恃絶すれば，脳の一部は 完全に或は永久に破壊される事を挙げて，その効 果を否定した。

Paul Cossa 氏 ${ }^{12)}$ は顔面神経麻㾝の生じた直後 
几麻㾢側の星状神経節を迕断すれば，血行が促進し，よ

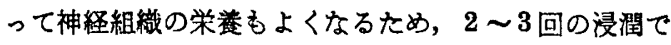
顔面神経麻㾝を殆んど完全消失させうるという。

1935年，フランスの Leriche 氏 ${ }^{13)}$ 等は四肢の有痛性 閉塞性動脈疾患時飞塩酸 Procaine を動静脈内飞注入し て，その血管氫孌を除去する事が出来るといい，その治 奻作用は疗禁状態にある小牛脈，毛細管壁の Louget 細胞に直接作用して血拡管張を起すためであると発表し た. その後，塩酸 Procaine の作用に関して北川氏7)は 血管内に入った塩酸 Procaine は 1 末梢動脈及び毛細血 管に直接作用して，これを拡張し，(2)抗 Histamine 作 用をなし，(3)交感神経節での Acetylcholin の産生を抑 制してその感受性を低下させ，且，(4)末梢神経の痛覚受 容器, 自律神経の器官受容器, 感覚受容器等を遮断して, 神経䄉維の陰 ion 交流が抑制され，膜表面の電位差を 不能飞し，神経伝達の低下，中枢性疼痛閾値の低下を招 来し，また，横紋筋と平滑筋の氫卛を除去し，温熱中枢， 自律神経中枢にも作用すると発表した。 また Graubard

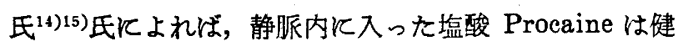
康部よりも炎症または㾏揫状態にある病態に特に高濃度 飞集積し，該部の病的反射を遮断してVasospasm，浮 腫等を除去し，血管㹡張を招来するといっている。一方 Outland 氏 ${ }^{16)}$ は Hypoxemia を改善して Tissue Hypoxia を恢復させると同時に自律神経末端に直接作用し， その不均衡を除去するためであるといっている. これら を綜合して見るに，塩酸 Procaine 静注はその侵襲点か らみて, Vascular lesion 飞対する適正な治療法である と考えられる。

Pratt 氏 ${ }^{17)}$ と Hohf 氏等 ${ }^{18)}$ は動脈であれ静脈であれ 大きな血管が直接或は間接に外甥を受けると Reflex syndrome が生じ，血管の氫摹を起して血管内皮には血 栓が形成され，この血栓によって血管痙孚は更に悪化さ れるといった，この様な場合には，交感神経を遮断して 座攀自体を減退せしめ, 同時に Anticoagulants を使 用して，血管内皮に括ける血栓形成を防止或は既飞形成 されたものを液化させねばならないといっている。

本実験成績の結果を見ると，塩酸 Procaine 注射群は 湯伤部血管の血栓形成が非注射例よりも約 $1 \sim 3$ 日遅れ， また組織壊死の程度も少い. しかし, 家兔の耳款は薄く, 血管分布も表在性であるので，局所浸潤時には注入液に よって血管が圧迫され，末梢部ではかえって整し血流が 杜絶して局所の貧血を起していた．また形成された水泡 が破垻して乾燥結痂すると，血管も同時に乾燥するので，

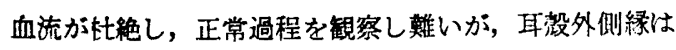
比校的厚く，ここで壏酸 Procaine の教果を証明する事
が出来た.

塩酸 Procaine の用量飞関して林氏 ${ }^{19}$ は成人に拈いて， 総 $1.0 \sim 3.0 \mathrm{gm}$ を毎時間静注する事が出来るといい, 北川氏7) 性成人男子飞机ける安全量を每時間 3.5 4.3 $\mathrm{mg} / \mathrm{kg}$ といっている. 成人と括いては每分 $19 \sim 20 \mathrm{mg}$ の Procaine が Serum cholinesterase とよって分解さ れるので，血液中に蓄積される事がなく，一時炕大量を 注入しない限り安全で, 副作用が発生しない程度に徐々 飞注入するならば，比較的多量の塩酸 Procaine を使用 する事が出来る。したがって局所浸潤時には静脈注射時 の 5 倍量を使用する事が出来るという. ${ }^{20)}$ Eggleston と Hatcher 両氏 ${ }^{20)}$ は猫に塩酸 Procaine を静注する時の 最少致死量を 40 45 mg であると報告している。

著者の実験では, 家鬼に対する塩酸 Procaine の中毒 量及び最少致死量は $1 \%$ 溶液を使用する時は平均 16.9 $27.9 \mathrm{mg} / \mathrm{kg}, 0.5 \%$ 溶液を使用与る時は $18.1 \sim 35.4 \mathrm{mg} /$ $\mathrm{kg}, 0.25 \%$ 溶液を使用する時は $17.9 \sim 35.4 \mathrm{mg} / \mathrm{kg}, 0.1$ \%溶液を使用する時は $19.8 \sim 34.2 \mathrm{mg} / \mathrm{kg}$ であり，低 濃度溶液を使用する程比較的多量の塩酸 Procaine を副 作用なしに使用することができた.

また，体重 $1 \mathrm{~kg}$ 当り $2 \mathrm{mg}$ の塩酸 Procaine を使 用した例では，その効果が微弱であり， $8 \mathrm{mg} / \mathrm{kg}$ 投与 例では身体均衡の岥失等, 多少の副作用を認めた. 家鬼 耳殼湯賃に対する塩酸 Procaine 静注時の有効量は体重 $1 \mathrm{~kg}$ 当り $4 \sim 6 \mathrm{mg}$, 無効量は $2 \mathrm{mg} / \mathrm{kg}$ 以下, 中毒 量は平均 $18.1 \sim 33.2 \mathrm{mg} / \mathrm{kg}$ と思はれる.

\section{VI. 結 論}

家鬼耳殼湯傷時, 実験的に観察せる塩酸 Procaine の 効果は次の如くである.

（1）湯傷時の熄酸 Procaine 療法は血管内の血栓形成 を遅起させ，組織の坮死を或る程度まで救出する。

（2）湯傷に括ける熄酸 Procaine の治効作用は局所浸 潤法, 交感神経節遮断法よりも静脈注射の方が最も効果 が良好である。

(3) 湯稘後 Procaine 療法を始めるまでの時間は, 受 賃直後から 6 時間まではその効果に大異なく, 有効であ ったが，12時間を過ぎれば湯伤部組織の救出は僅少であ っ.

（4）湯賃に対する塩酸 Procaine の有効量は体重 $1 \mathrm{~kg}$ 当り $4 \sim 6 \mathrm{mg}$, 無効量は $2 \mathrm{mg}$ 以下, 中毒量は 18.1 〜33. $2 \mathrm{mg}$ であった.

$$
\text { 文献 }
$$

1) A. B. Bishnevsky. : Chirurgie, 1946.

2) Traut. : J. A. M. A., $150: 785,1952$. 

3) Gillespie, Henderson. : U. S. A. F. Med. J., IV, 987, 1953.
4) J. E. Ruben, R. A. Mayer. : J. A. M., 153 : 1002, 1953.
5) C. H. Millikan, J. S. Lundy, L. A. Smith. : J. A. M. A., 151 : 438, 1953.
6) Betcher, Bean, Casten. : J. A. M., $151: 288,1953$.
7) 北川信太郎：日本医事新報；1588:4162, 昭29年
8) 栗秋要 : 綜合医学, $11: 265$, 昭29年
9）岩森资外：臨床外科，11:175，昭31年
10) De Takats. : J. A. M. A., 157 : 1219, 1955.
11) W. C. Alvarez. : J. A. M. A., 157, 1955.

12) Paul Cossa. : 1945.

13) R. Leriche. : Progres Med., 70 : 443, 1942.

14) D. G. Graubard. : New York State. J. M., 47 : 2187, 1949.

15) D. J. Graubard. : Am. J. Surg., 74 : 765, 1950.

16) T. Outland, C. R. Haulton. : J. A. M. A., 114 : 1330, 1940.

17) G. H. Pratt. : J. A. M. A., 152 : 903, 1953.

18) R. P. Hohf et al. : J. A. M. A., $152: 399,1953$.

19）林睠：日本医事新報：1479:2954, 昭27年

20) Sollmann. : A manual of pharmecology, Saunders Co.

\title{
Experimental Study of the Action of Procaine hydrochloride on Scalds on Rabbit's Ear
}

\author{
by

\section{Kyou Chull Chung} \\ Postgraduate School, Seoul National University
}

It is a well known fact through literatures that there is a functional relationship between various disease symptom complexes and sympathetic nervous system, and although the disharmony or the disfunction of the sympathetics is not a causal factor of the diseases, the correction of the disintegrated function using procaine hydrochloride invites the relief or improvement of those symptom complexes.

To invesigate the action of procaine hydrochloride on scalds on rabbit's ear, the author have made the experiments with rabbits treated with $70^{\circ} \mathrm{C}$. hot water for 5 minutes on their ears to figure out 1 ) the influence of procaine hydrochloride on the lesion, 2) the amounts of effective, non-effective and toxic doses, 3) the route of administration preferred to gain better effect, and 4) the frequency of the administration of the drug.

The results obtained are as follows:

1) Procaine therapy on scalds on rabbit's ear favors to prolong the formation of thrombi in affected vessels, and save the tissue from necrosis.

2) The action of procaine hydrochloride on scalds on rabbit's ear differs by the route of its administration. Intravenous administration of the drug is most effective than local block or sympathetic ganglion block.

3) There is no peculiar difference in its effectiveness among those to which the procaine therapy is performed immediately after and six hours after the scalds. Those, however, to which procaine therapy is instituted twelve hours after the scalds shows less effectiveness in saving the affected tissue from necrosis. Repeated injection every twenty-four and seventy. two hour intervals does not influence to the disease process.

4) Effective dose of procaine hydrochloride on scalds on rabbit's ear shows 4 6mg., non-effective dose less than $2 \mathrm{mg}$. and toxic dose $18.1 \sim 33.2 \mathrm{mg}$. per kilogram of body weight in average when administered intravenously. 